\title{
Statyba
}

\section{MODELLING OF CRYOGENIC STRUCTURE UNDER SEISMIC LOADING}

\section{R. Kačianauskas \& R. Kutas}

To cite this article: R. Kačianauskas \& R. Kutas (1995) MODELLING OF

CRYOGENIC STRUCTURE UNDER SEISMIC LOADING, Statyba, 1:1, 59-75, DOI:

10.1080/13921525.1995.10531502

To link to this article: https://doi.org/10.1080/13921525.1995.10531502

曲 Published online: 26 Jul 2012.

Submit your article to this journal $\pi$

山 Article views: 79

4 Citing articles: 1 View citing articles 진 


\section{MODELLING OF CRYOGENIC STRUCTURE UNDER SEISMIC LOADING}

\section{R.Kačianauskas, R.Kutas}

\section{Introduction}

One should realise that seismic analysis or, more generally. seismic modelling and design under seismic loading is still as much an art as it is a science. A general consensus of the appropriate approach does not yet exist. Our intention is to demonstrate the seismic modelling possibilities on the example of the cryogenic structure using finite element method.

The fundamentals of the seismic analysis as a part of structural dynamics are presented in [1] which includes basic computational rules and structural examples. Recent presentation of the state of art in this field is provided in [2]. This book represents an attempt to bridge the persisting gap between advances in the theory and concept of earthquake engineering design. Details of the finite element technique may be found in [3].

In order to design a structure to withstand an earthquake, the forces must be specified. The exact forces that will occur during the life of a structure cannot, of course, be known. A realistic estimate is important, however, since the cost of construction, and therefore the economic viability of the project, depends on a safe and cost-efficient final product.

The seismic forces acting in a structure depend on a number of factors, including the characteristics of the earthquake, the site geology, structure properties and importance, etc. These factors should be reflected in the specification of seismic forces.

In this presentation, the cryogenic structure under action of different seismic loads is tested numerically by the finite element method. Two kinds of factors for seismic models are investigated. The first factor considered reveals the influence of various loads to the one of structural models. For this purpose time-dependent analysis under action of one of the most damaging earthquakes in its recorded history, Mexico earthquake $[4]$ is performed and compared to the results obtained by still existing (ivil Engineering Design (ode (CEDC) [5] and recommendations for the Nuclear Power Design Code (NPDC) $|6|$ of former Soviet Union. The comparison of different discretisation schemes under action of simplified seismic loads is provided as the second modelling factor. The engineering design codes mentioned above are implemented into finite element software developed in the Laboratory of Numerical 
Modelling and Research of Structures of Vilnius Technical University 17, 8]. The current approach is briefly presented in [9].

\section{Mathematical models}

There are two commonly used procedures for specifying seismic forces: time-dependent dynamic analysis and equivalent static force procedure. In a general case, a dynamic analysis should be used to specify distributed design forces. It should take account of the structure dynamic characteristics, including vibration frequencies, mode shapes and damping. The dynamic analysis for the dynamic motion of a structure simply means time-varying or transient analysis. This results in infinite number of possible solutions during the time interval under consideration. From the engineering standpoint, the maximum values of the earthquake structural response are usually the ones of particular interest. An arbitrary time-history can be represented by a series of short duration impulses and dynamic response of single impulse is expanded to produce an arbitrary response. Since the amount of computations is rapidly growing the time-history models may be excessive. On the other hand, this model may be used not directly for computation of design stresses but for estimation of possible damages.

The time dependent analysis is carried out on the basis of equation of motion. For seismic analysis, the discrete dynamic equilibrium model or transient model is written as

$$
[M] \ddot{U}(t)+[C] \dot{U}(t)+[K] \boldsymbol{U}(t)=\boldsymbol{F}_{\text {seis }}(t) .
$$

Here, $[M],[C]$ and $[K]$ are given mass, damping and stiffness matrices of conventional finite element systems while $F_{\text {seis }}(t)$ is the vector of seismic load. The time-dependent unknown function $U(t)$ stands for the nodal displacements, $\dot{U}(t)=\mathrm{d} U(t) / \mathrm{d} t$ for velocities and $\ddot{U}(t)=\mathrm{d}^{2} U(t) / \mathrm{d} t^{2}$. When a structure is subjected to a sudden ground acceleration $a$, the $i$-th component of seismic load develop according to Newton's second law

$$
F_{\text {seis } i}(t)=m_{i} a(t)
$$

where $m_{i}$ is corresponding mass. The main difficulty in practical application of (1-2) is how to choose the required acceleration. For this purpose, the required earthquake accelerograms are used.

However, from a practical standpoint, it is very important to introduce simplified seismic analysis models. In the equivalent static force models, the inertial forces are specified as static forces using empirical formulas. The explicit formulas were, however, developed for the simplest structures. The specification of seismic forces is provided by corresponding design codes. The philosophy of a particular document indicates the general level of protection that it can be expected to provide. The code-specified 
forces are generally lower than those that would occur in a large or moderate earthquake. It is assumed that the larger loads that actually occur will be accounted for by the additional factors of safety and by redundancy of the system.

In general, the engineering models represent an envelope of possible values and may be presented in the following way. The simplified seismic analysis is considered as a particular case of the linear static analysis model and is expressed by a conventional displacement equilibrium equation

$$
[K][U]_{S}=[F]_{S}
$$

Here, $[F]_{S} \equiv\left[\boldsymbol{F}_{S 1}, \boldsymbol{F}_{S 2}, \ldots, \boldsymbol{F}_{S i}, \ldots, \boldsymbol{F}_{S m}\right]$ and $\left[U_{S} \equiv\left[\boldsymbol{U}_{S 1}, \boldsymbol{U}_{S 2}, \ldots, \boldsymbol{U}_{S i}, \ldots, \boldsymbol{U}_{S m}\right]\right.$ stand for a given seismic load and unknown displacement matrices, where $m$ is a number of considered loads. The loading matrix describes a truncated set of the lowest free vibration modes. If we express the free-vibration problem (304) as a generalised eigenvalue problem

$$
[K][X]-[\omega]^{2}[M][X]=[O]
$$

model (4) produces a set of eigenvectors (modal co-ordinates) $[X]$, while the values of the diagonal matrix $[\omega]^{2}$ are squared frequencies of the structure. The seismic load vectors $F_{S i}$ corresponding to an individual mode $i$ may be expressed by eigenfrequency $\omega_{i}$, mode shape vector $\boldsymbol{X}_{i}$, global mass matrix $[M]$ and some other preliminary defined factors

$$
F_{S i}=F_{S i}\left(\omega_{i}, X_{i},[M], \ldots\right)
$$

For the sake of simplicity, dynamic behaviour of complex structures is represented by the behaviour of the simplest prototype. Substructuring, physical co-ordinates, macroelements and other multilevel discretisation techniques are used for the definition of expression (5). The models in the form of bending cantilever beam are frequently used for modelling of buildings. The main drawback of the model (3) is that the number of modes $m$ which should be retained for seismic analysis is unknown and not all the modes occur at the same time. As a rule, the modal responses were combined using the complete quadratic combination method, where typical stress (force) component $\sigma$ is expressed as a combination of $m$ modes

$$
\sigma=\sqrt{\sum_{i=1}^{m} \sigma_{i}^{2}} .
$$

Various national and even regional codes and recommendations provide different specification of a seismic load (5). Perhaps most simple model is specified by Civil Enginecring Design Code [4]. Here, 
individual component $j$ of seismic load $F_{S i} \equiv\left\{F_{S i 1}, F_{S i 2}, \ldots, F_{S i j}, \ldots, F_{S i n}\right\}^{\mathrm{t}}$ is displayed by a simple formula

$$
F_{S i j}=\alpha_{1} \cdot \alpha_{2} \cdot \ldots \cdot \alpha_{k} \cdot G_{j},
$$

where $G_{j}$ is the dead gravity load of a structure referred to node $j(j=1, n)$ while $\alpha_{1}, \alpha_{2}, \ldots, \alpha_{k}$ represent a set of the specified factors. One of them $\alpha_{1}$ depends on intensity magnitude $s_{m}$ defined by Richter scale. Richter magnitude scale is defined as logarithm to base ten of the maximum seismic wave amplitude in microns recorded on seismograph located at a distance of $100 \mathrm{~km}$ from the earthquake epicenter. For example, if magnitude $s_{m}=7$ then $\alpha_{1}=0.1$, if $s_{m}=8$ then $\alpha_{1}=0.2$, if $s_{m}=9$ then $\alpha_{1}=$ 0.4 . If a multi-storey building may be simplified to cantilever model, the contribution of individual mode $i$ in node $j$ is expressed by factor $\alpha_{2} \equiv \eta_{i j}$

$$
\eta_{i j}=\frac{\tilde{x}_{i j} \sum_{p=1}^{N} G_{p} \tilde{x}_{i p}}{\sum_{p=1}^{N} G_{p} \tilde{x}_{i p}^{2}}
$$

where $\tilde{x}_{i j}$ is the projection of mode shape vector $i$ in node $j$ into the direction of seismic load. The number of modes involved is not strictly defined but is restricted by vibration period $T \geq 0.4 \mathrm{~s}$. Other factors depend on building properties, ground, etc.

The recommendations for design of nuclear power equipment [6] use more exact higher-order model based on response spectra technique. The response spectra technique assumes approximation of maximum of total values of response parameters against frequency characteristics. The earthquake responses of standard systems with a single degree of freedom using generalised co-ordinate approach are extended to complex systems. The design spectra should be obtained by the selection of possible earthquake motions that could be experienced of the site statistics and used to create a smooth spectrum of some suitable design level. The design forces are given in simplified version of modal analysis which is now applicable in the form of equivalent static forces. It provides an envelope of response parameter plotted as a function of the natural period of a standard oscillator. Finally, the seismic load component analogous to (7) is expressed as

$$
F_{S_{i j}}=m_{j} \ddot{a}_{i} \eta_{j} x_{i j}
$$

Here, $m_{i}$ is nodal mass, $\ddot{a}_{i} \equiv \ddot{a}_{i}\left(T_{J}, \psi\right)$ is a specified acceleration of a standard oscillator depending 
on vibration period $T_{j}$ and damping factor $\psi$, while $\eta_{i j}$ is a mode shape factor which is defined in similar way as (8)

$$
\eta_{j}=\frac{\sum_{p=1}^{N} m_{p} \tilde{x}_{i p}}{\sum_{p=1}^{m} m_{p} x_{i p}^{2}}
$$

Here, $x_{i j}$ and $\tilde{x}_{i j}$ are the mode shape values and their projections to seismic direction. The admissible vibration spectrum is restricted by frequency equal to $24 \mathrm{~Hz}$.

Both time-dependent dynamic model (1-2) as well as the equivalent static force models $(3-5),(7-8)$ or (3-5), (9-10) are used for the estimation of enveloping stresses.

\section{Description of the Structure}

Cryogenic equipment is built up as a large metal box intended for cryogenic technologies. The box consists of a three-dimensional frame covered by thin metal sheets. The structure is additionally stiffened by an external frame-type structure also used for technological service. The material of the structure is taken as being linear elastic and is defined by three dependent characteristics such as Young's modulus $E=2.1 \cdot 10^{5} \cdot \mathrm{MPa}$, Poisson's ratio $v=0.25$ and mass density $\rho=7800 \mathrm{~kg} / \mathrm{m}^{3}$.

The geometry and the dimensions of a hermetic part of the structure are presented in fig. 1. According to design requirements the frame members are made of standard welded profiles. The structure contains five profiles illustrated in fig. 2. The cross-sectional characteristics of the profiles are presented in table 1 . The first profile is used for corner columns, the second profile is used for a wall column, the third - for horizontal beams, while the fourth as well as fifth profiles are used for an external frame. The thickness of covering sheets $t$ is taken as $t=2 \mathrm{~mm}$.

Table 1. Geometric characteristics of profiles

\begin{tabular}{|c|c|c|c|c|c|}
\hline $\begin{array}{c}\text { Profile } \\
\text { No }\end{array}$ & $\begin{array}{c}\text { Area } \\
A\left(\mathrm{~cm}^{2}\right)\end{array}$ & $\begin{array}{r}\text { Axial } \\
\text { moment } \\
I_{y}\left(\mathrm{~cm}^{4}\right)\end{array}$ & $\begin{array}{r}\text { Axial } \\
\text { moment } \\
I_{7}\left(\mathrm{~cm}^{4}\right)\end{array}$ & $\begin{array}{r}\text { Torsion } \\
\text { moment } \\
I_{T}\left(\mathrm{~cm}^{4}\right)\end{array}$ & $\begin{array}{c}\text { Eccentr. } \\
\text { moment } \\
I_{2 \mathrm{z}}\left(\mathrm{cm}^{4}\right)\end{array}$ \\
\hline \hline 1 & 81.0 & 12352.1 & 9290.3 & 26.4 & 4428.0 \\
\hline 2 & 111.6 & 18567.3 & 4068.3 & 130.3 & 0. \\
\hline 3 & 81.0 & 11620.0 & 1168.3 & 54.3 & 0. \\
\hline 4 & 130.5 & 12560.0 & 846.0 & 281.0 & 0. \\
\hline 5 & 61.2 & 5800.0 & 774.0 & 31.0 & 0. \\
\hline
\end{tabular}


The mass required for seismic analysis is taken as a mass of structural members, a mass of covering and an external mass of equipment aided to structure. The mass of structure and mass of covering are formed by lumping at nodes. The location of external mass is shown in fig. 1 , where $m_{1}=900 \mathrm{~kg}$ and $m_{2}=1200 \mathrm{~kg}$.

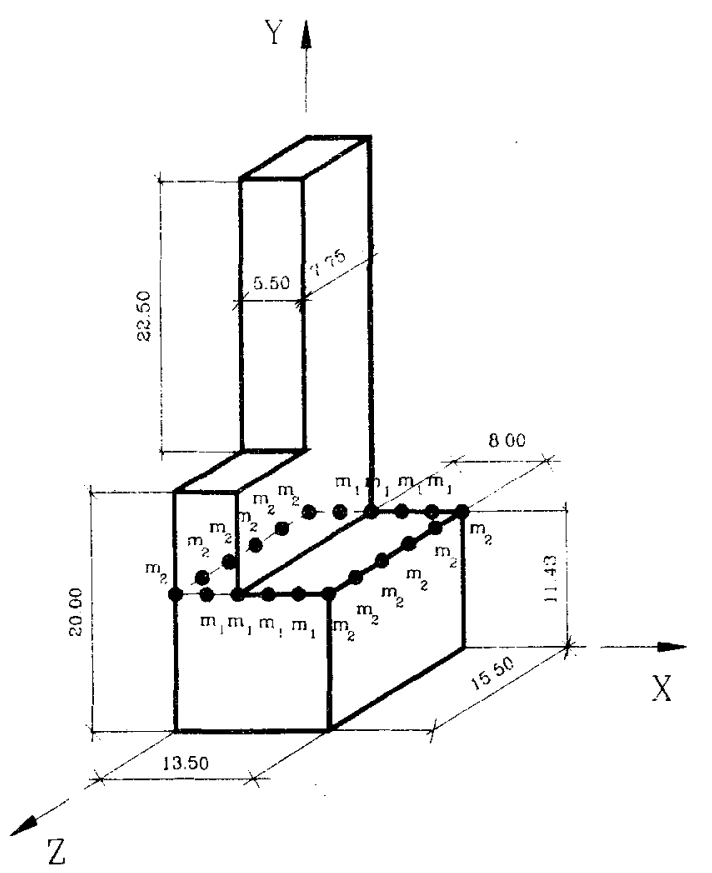

Fig. 1. Geometry and lumped mass loading of the structure

a)

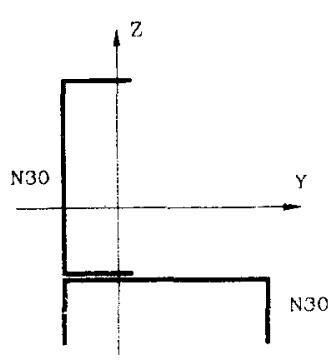

b)

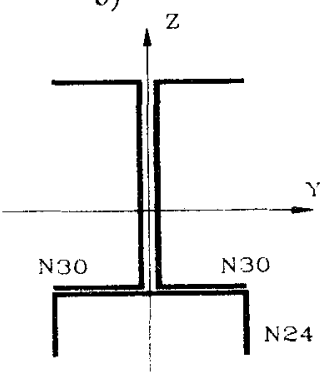

c)

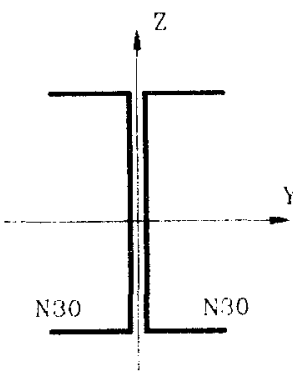

d)

d)

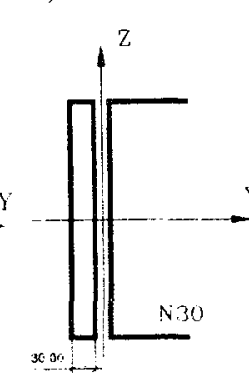

e)

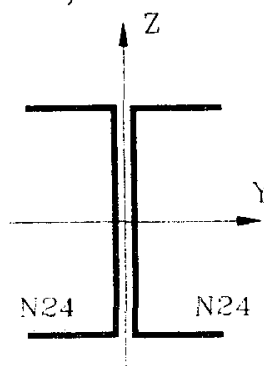

Fig. 2. Cross-sections of the structural members:

a) corner columns; b) wall columns; c) horizontal beams; d-e) external frame 
For numerical analysis the cryogenic structure is presented as an assemblage of beam type finite elements rigidly connected at nodes. The elements used are of two types: a classical three-dimensional beam element FRM3 and a generalised beam element CFRM [7]. The classical element describes uncoupled axial, bending and torsion deformations of symmetric cross-section. The general element may describe coupling of bending with shear, bending with axial deformations as well as coupling of bending in both planes of uniform cross-section. The latest deformation mode is accepted in the element when it has non-zero eccentric moment of inertia $I_{y z}$. The element CFRM is used to describe the shifting of a mass center of the element section with respect to a finite element grid. The main difference between the above elements lies not only in the formation of the stiffness matrix but also in computation of stresses. The first element simply deals with the sectional moments while for the second general element the tensopoints have to be defined. The covering of the structure is modelled by a special wall element PANL [7]. The total view of a finite element model is presented in fig. $3 \mathrm{a}$, while fig. $3 \mathrm{~b}$ illustrates the fragment of the model with shrank elements. A discrete model assumes the above structure to be assembled of classical beam elements and complex wall elements. The development of characteristic matrices of the wall elements is a lower-level modelling procedure. In the context of general seismic analysis, this two-level discrete model may be used by formulation of the linear static analysis (3), frequency analysis (4) or linear transient analysis (1) problems. However, the main idea of the computation of the seismic loads (3-10) rests on a more simple global model considering the structure as a simple cantilever. It means that actual seismic loads reflect the dynamic behaviour of a complex structure by only a small number of external degrees of freedom (the lowest vibration modes).

a)

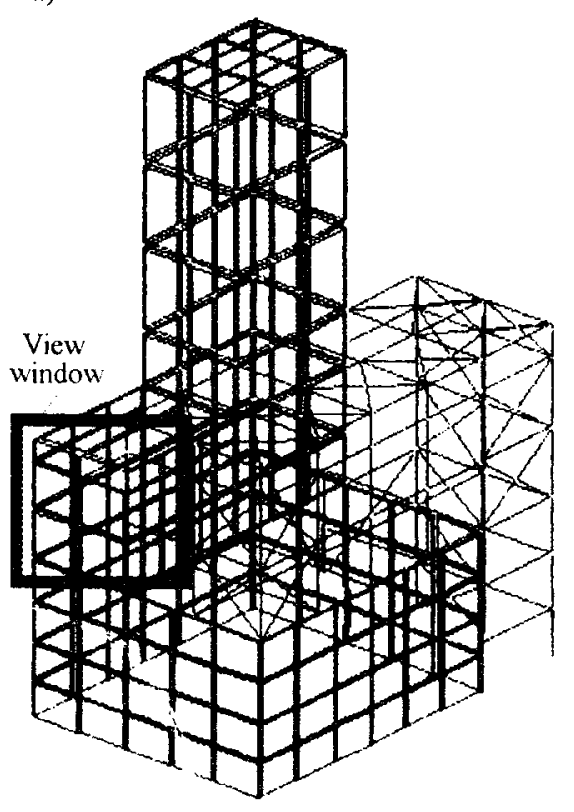

b)

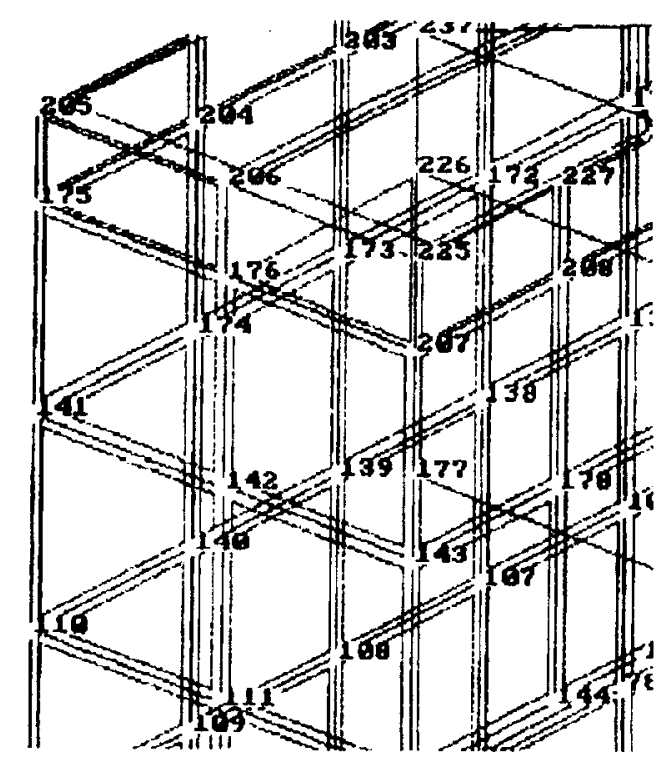

Fig. 3. Finite element model of cryogenic structure: a) entire view: b) fragment with shrank elements 


\section{Numerical results.}

For design purpose a detailed time-dependent seismic analysis (1-2) is replaced by more simple equivalent static force models (3-10) the methodology of which is defined by particular design codes. In this presentation, the cryogenic structure under the action of different seismic loads is tested numerically by the finite element method. Two kinds of factors influencing seismic models are investigated. The first factor considered reveals the influence of various loads on one of the structural models

Different models representing the above structure and seismic loading are tested numerically in order to recover the main features and to obtain enveloping results. The maximum normal stresses are chosen as modelling parameters. For this purpose a typical most heavily loaded horizontal beam and a corner column are taken as illustration.

The first group of examples investigate the frame of a structure without the covering subjected to different seismic loads. The horizontal component of 1985 Mexico earthquake [4] acting in plane $O y z$ (fig. 4) is used for time-dependent analysis. It was a unique and most damaging earthquake in its recorded history having a very regular motion and a very long duration.

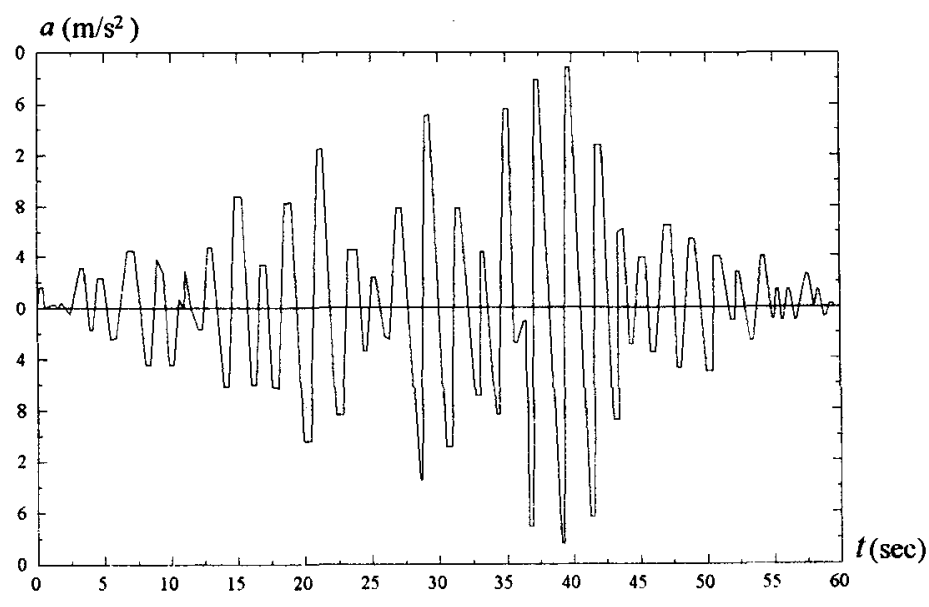

Fig. 4. Horizontal accelerogram of 1985 Mexico earthquake - acceleration $a$ versus time $t$.

The direct integration of equations (1) was used by applying different time increment values $\Delta t$. For the evaluation of maximum stresses the effect of damping is neglected. Figures $5 \mathrm{a}$ and $5 \mathrm{~b}$ illustrate the history of stresses of most stressed horizontal beam and corner column, respectively. The more rough time approximation with the time increment $\Delta t=0.1135 \mathrm{sec}$ was used for the whole time history, while the refined time approximation with the time increment $\Delta t=0.0445 \mathrm{sec}$ was used for the region of maximal loading. The first scheme provides the maximum stress $\sigma_{\max }=246.9 \mathrm{MPa}$ for the beam and $\sigma_{\max }=200.3 \mathrm{MPa}$ for the column. The refined model reflects the influence of higher-order frequencies 
and finally leads to a larger value of maximum stresses $\sigma_{\max }=302.3 \mathrm{MPa}$ for the beam and to $\sigma_{\max }=$ 224.6 MPa for the column.

a)

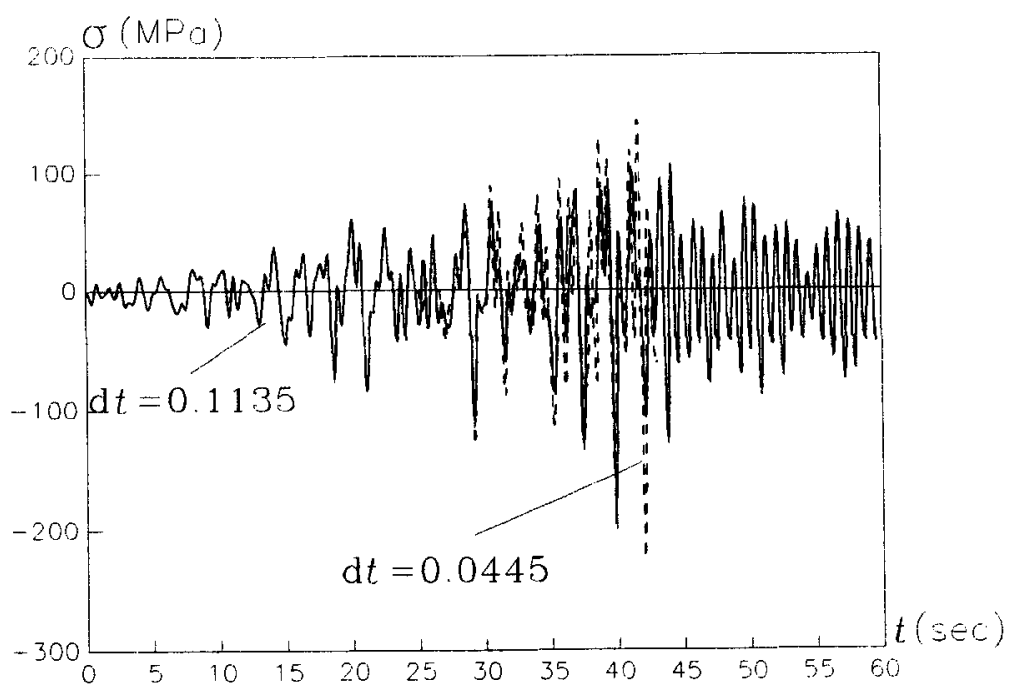

b)

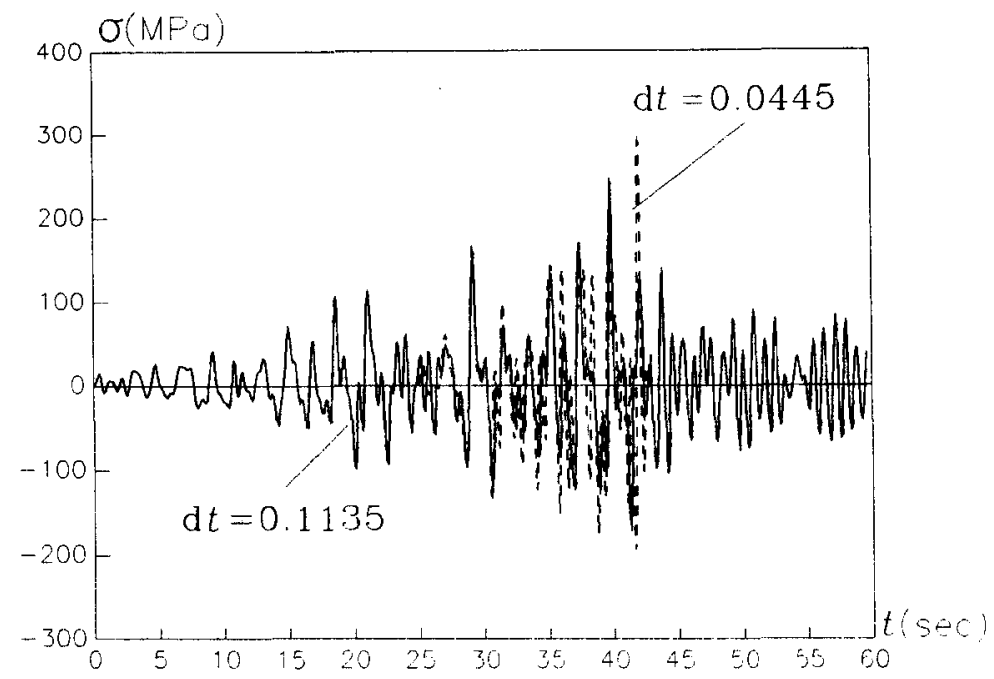

Fig. 5. Variation of stresses in time-history analysis: a) for characteristic column; b) for characteristic beam;

For the evaluation of a seismic load according to a simplified model (3-10) the frequency analysis problem (4) was solved. The eight lowest free-vibration modes are taken into consideration. The projections of modes into plane $O x y$ are presented in fig. 6. The shapes of the first four lowest free vibration modes (fig. $6 \mathrm{a}-\mathrm{d}$ ) of the structure correspond to the modes of cantilever beam model related to bending coupled with torsion. while the next four modes (fig. 6e-h) are merely related to the deformations of the cross-section. 
a)

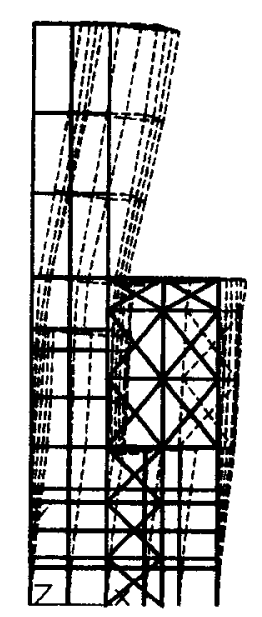

d)
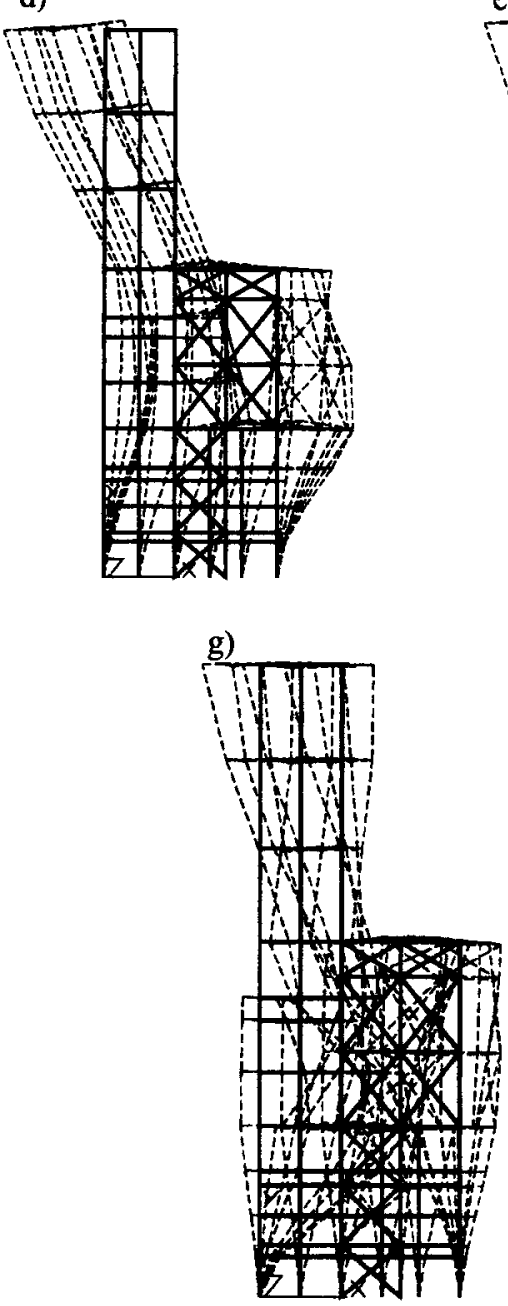

b)

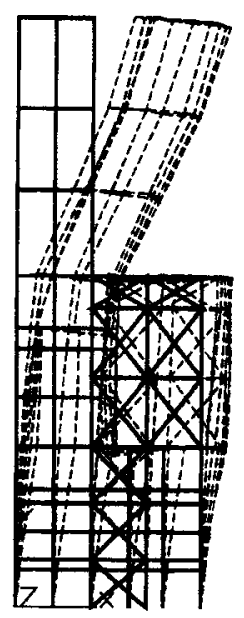

e)

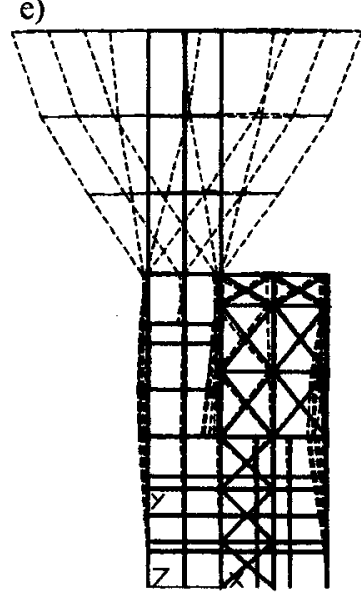

c)

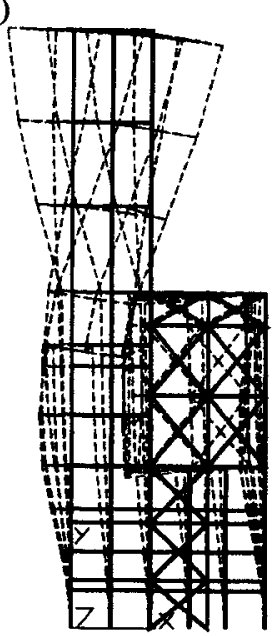

f)

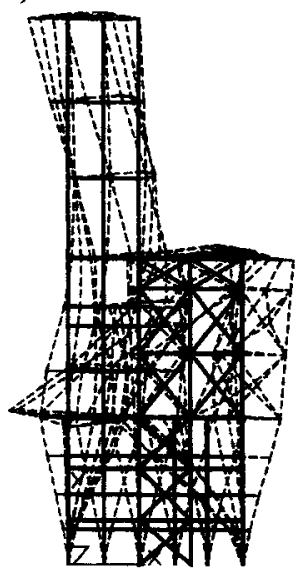

Fig. 6. The lowest free-vibration modes of structure 
According to the CED Code [5], the seismic load is calculated by expression (7). Numerical values of maximum stresses for the characteristic (maximally stressed) horizontal beam and corner column corresponding to different magnitudes of Richter scale $s_{m}$ are selected in the tables 2 . The tables contain values increasingly arranged due to contribution of individual modes. The same results of computations of stresses according to recommendations of NPD, where seismic load is expressed by (9), are also selected in table 2. The obtained stresses are graphically illustrated in fig. 7. Here, time-history of maximum stresses in selected region is compared to the values of engineering models. The influence of the particular code methodology, of the seismic loading magnitude $s_{m}$ (according to Richter scale) and the contribution of individual vibration modes are reflected and may be estimated on basis of these results.

Table 2. Comparison of maximal stresses $\sigma_{\max }(\mathrm{MPa})$ due to different models of seismic loading: a) the values of stresses for horizontal beam

\begin{tabular}{|c|c|c|c|c|c|c|c|}
\hline \multirow{2}{*}{$\begin{array}{c}\text { Mode } \\
\text { number }\end{array}$} & \multicolumn{3}{|c|}{ Civil Engineering Code } & \multicolumn{3}{c|}{ Nuclear Power Code } & $\begin{array}{l}\text { Time- } \\
\text { depend. } \\
\text { analysis }\end{array}$ \\
\cline { 2 - 8 } & $\begin{array}{c}\text { Magnit. } \\
s_{m}=7\end{array}$ & $\begin{array}{c}\text { Magnit. } \\
s_{m}=8\end{array}$ & $\begin{array}{c}\text { Magnit. } \\
s_{m}=9\end{array}$ & $\begin{array}{c}\text { Magnit. } \\
s_{m}=7\end{array}$ & $\begin{array}{c}\text { Magnit. } \\
s_{m}=8\end{array}$ & $\begin{array}{c}\text { Magnit. } \\
s_{m}=9\end{array}$ & \\
\hline 1 & 3.158 & 6.316 & 12.632 & 9.288 & 18.576 & 37.153 & \\
\hline 2 & 11.379 & 22.758 & 45.516 & 31.685 & 63.370 & 126.739 & \\
\hline 3 & 12.174 & 24.348 & 48.696 & 33.473 & 66.947 & 133.894 & \\
\hline 4 & 27.730 & 55.461 & 55.461 & 69.547 & 139.094 & 278.188 & \\
\hline 5 & 27.755 & 55.511 & 111.022 & 69.599 & 139.198 & 278.395 & \\
\hline 6 & 28.988 & 57.976 & 115.952 & 71.920 & 143.841 & 287.682 & \\
\hline 7 & 30.049 & 60.099 & 120.198 & 74.364 & 148.728 & 297.457 & \\
\hline 8 & 30.514 & 61.028 & 122.056 & 75.494 & 150.989 & 301.978 & \\
\hline $\begin{array}{c}\text { Maxim. } \\
\text { values }\end{array}$ & 30.514 & 61.028 & 122.056 & 75.494 & 150.989 & 301.978 & 302.3 \\
\hline
\end{tabular}

b) the values of stresses for comer column

\begin{tabular}{|c|c|c|c|c|c|c|c|}
\hline \multirow{2}{*}{$\begin{array}{c}\text { Mode } \\
\text { number }\end{array}$} & \multicolumn{3}{|c|}{ Civil Engineering Code } & \multicolumn{3}{c|}{ Nuclear Power Code } & $\begin{array}{l}\text { Time- } \\
\text { depend. } \\
\text { analysis }\end{array}$ \\
\cline { 2 - 8 } & $\begin{array}{c}\text { Magnit. } \\
s_{m}=7\end{array}$ & $\begin{array}{c}\text { Magnit. } \\
s_{m}=8\end{array}$ & $\begin{array}{c}\text { Magnit. } \\
s_{m}=9\end{array}$ & $\begin{array}{c}\text { Magnit. } \\
s_{m}=7\end{array}$ & $\begin{array}{c}\text { Magnit. } \\
s_{m}=8\end{array}$ & $\begin{array}{c}\text { Magnit. } \\
s_{m}=9\end{array}$ & \\
\hline 1 & 7.250 & 14.501 & 29.002 & 21.322 & 42.645 & 85.290 & \\
\hline 2 & 25.435 & 50.870 & 101.741 & 70.842 & 141.684 & 283.369 & \\
\hline 3 & 26.202 & 52.405 & 104.810 & 72.561 & 145.123 & 290.246 & \\
\hline 4 & 41.045 & 82.090 & 164.181 & 106.021 & 212.042 & 424.085 & \\
\hline 5 & 41.049 & 82.099 & 164.199 & 106.030 & 212.061 & 424.123 & \\
\hline 6 & 41.210 & 82.420 & 164.840 & 106.322 & 212.644 & 425.289 & \\
\hline 7 & 41.353 & 82.706 & 165.412 & 106.638 & 213.277 & 426.555 & \\
\hline 8 & 41.556 & 83.112 & 166.225 & 107.112 & 214.225 & 428.451 & \\
\hline $\begin{array}{l}\text { Maxim. } \\
\text { values }\end{array}$ & 41.556 & 83.112 & 166.225 & 107.112 & 214.225 & 428.451 & 224.6 \\
\hline
\end{tabular}




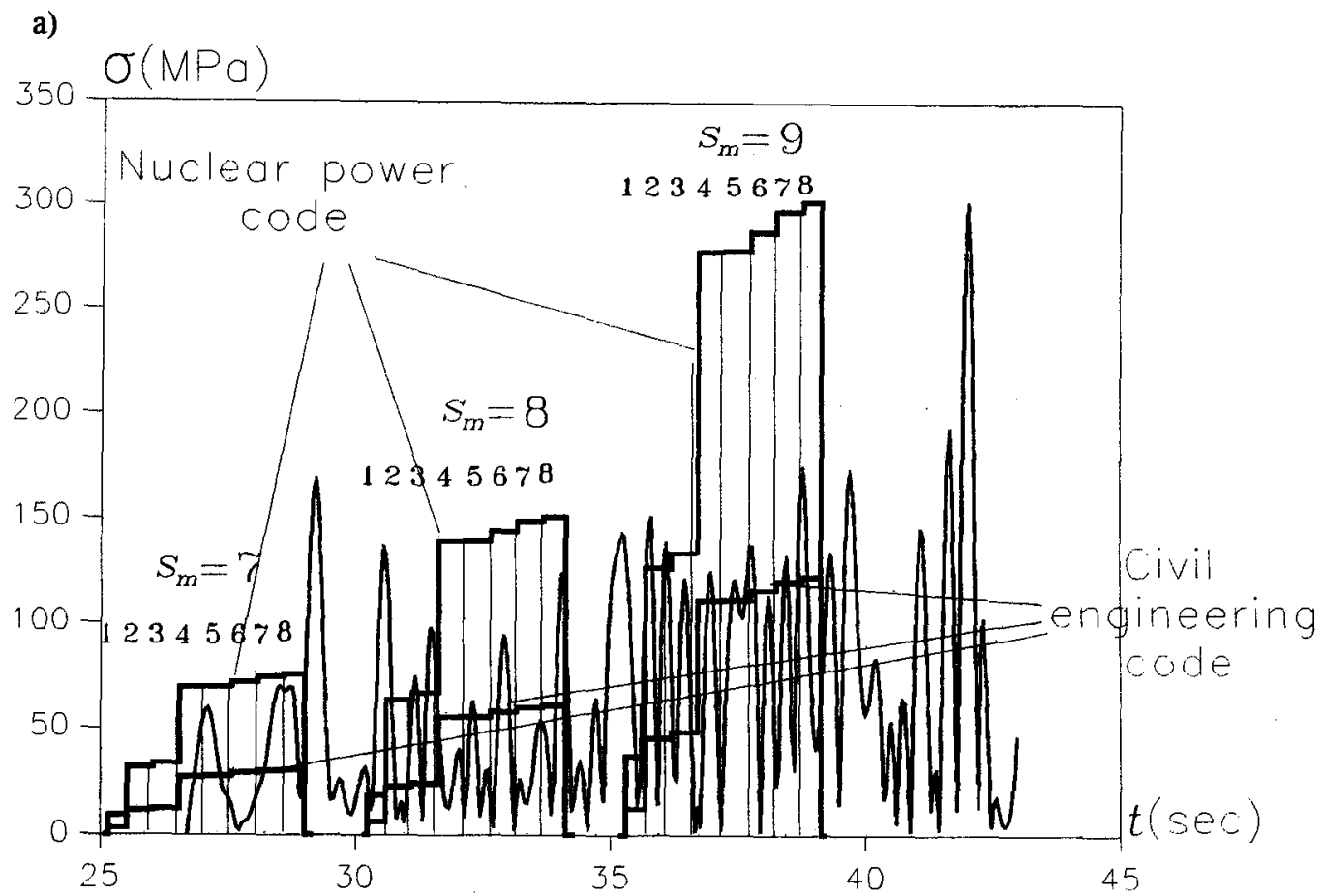

b)

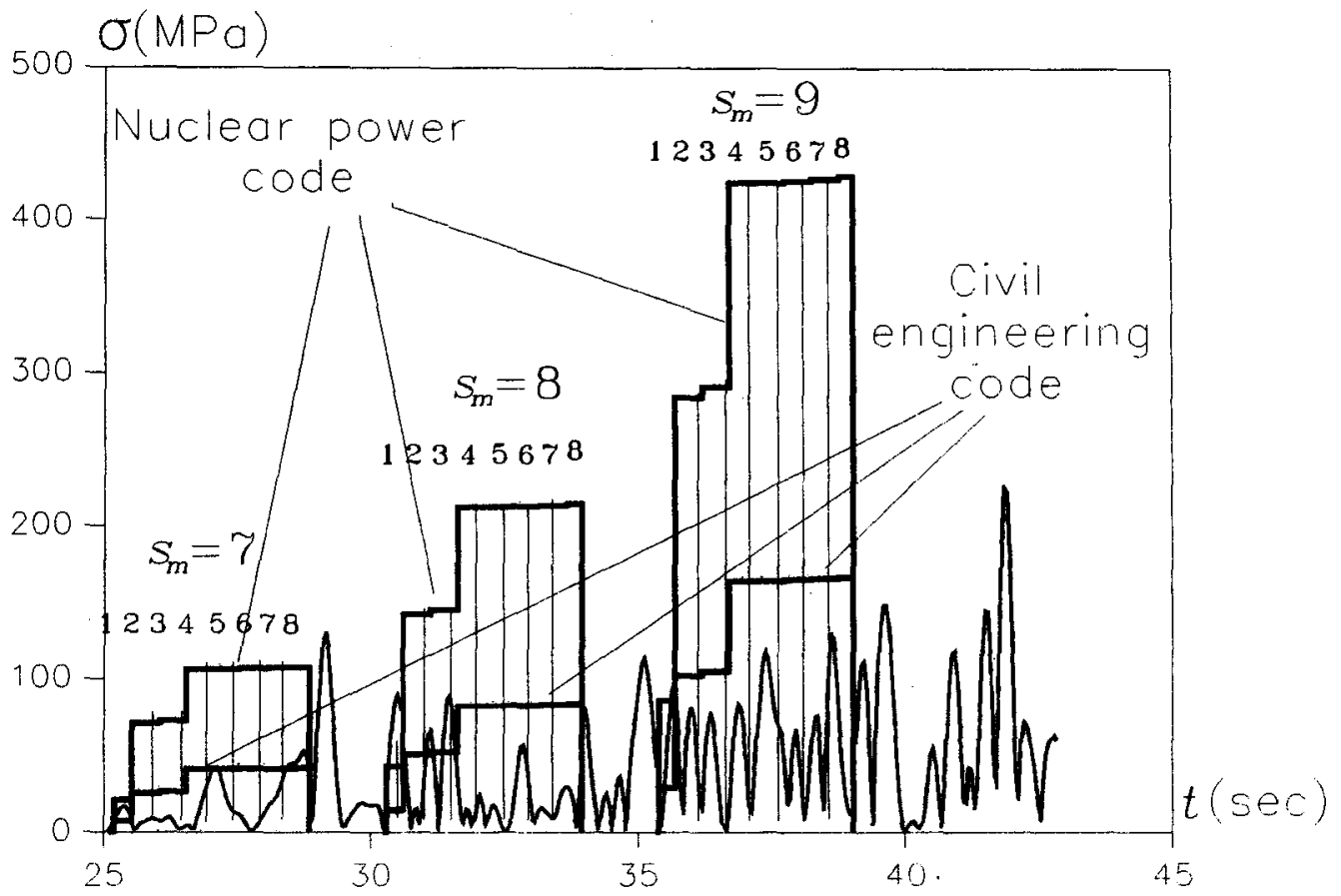

Fig. 7. Comparison of different models:

a) maximal stresses in characteristic horizontal beam;

b) maximal stresses in characteristic column 
Theoretically, the simplified static methods should give an envelope of any real stress history. It is obvious that NPD Code provides a higher stress level and larger safety margin than CED Code does. This fact is, in general, observed in the results of modelling with the exception of a single peak value.

A comparison of different models illustrates the fact that for the beam the maximum damaging stress $\sigma_{\max }=302.3 \mathrm{MPa}$ computed by a time history model exceeds the stresses of the CED model $\sigma_{\max }=$ 122.1 MPa obtained for the Richter scale magnitude $s_{m}=9$ in order of 2.5 times and the maximum stresses $\sigma_{\max }=301.9 \mathrm{MPa}$ of a NPD model in order of 1.001 times. It means that simplified models can not estimate the scattering of seismic loads for such a dangerous earthquake.

The same comparative study for column stresses provides the highest time-dependent stress $\sigma_{\max }=$ 224.6 MPa which violates the enveloping stress $\sigma_{\max }=166.2 \mathrm{MPa}$ for a CED model, while lies below the enveloping stresses $\sigma_{\max }=428.4 \mathrm{MPa}$ obtained by an NPD model. It means that the design code methodology covers the peak values with the probability lower than $100 \%$.

A critical study of the role of separate vibration modes indicates that the contribution of the second as well as the fourth mode is dominating and provides approximately $77.5 \%$ of the total value for beams and columns. In general, these modes correspond to the bending deformations of the global model. The influence of higher modes is negligible small.

Table 3 . The values of free-vibration frequencies

\begin{tabular}{|c|c|c|c|c|}
\hline \multirow{2}{*}{$\begin{array}{c}\text { Mode } \\
\text { number } \\
i\end{array}$} & \multicolumn{4}{|c|}{ Frequencies $f(\mathrm{~Hz})$} \\
\cline { 2 - 5 } & Model 1 & Model 2 & Model 3 & Model 4 \\
\hline 1 & 1.164 & 2.247 & 1.147 & 2.500 \\
\hline 2 & 1.313 & 2.550 & 1.308 & 2.551 \\
\hline 3 & 1.660 & 3.061 & 1.632 & 3.059 \\
\hline 4 & 1.740 & 3.133 & 1.731 & 3.183 \\
\hline 5 & 2.063 & 3.552 & 1.930 & 3.552 \\
\hline 6 & 2.474 & 3.763 & 2.463 & 3.763 \\
\hline 7 & 2.849 & 3.878 & 2.792 & 3.878 \\
\hline 8 & 2.958 & 4.176 & 2.950 & 4.176 \\
\hline
\end{tabular}

The second group of examples is considered in order to compare different computational and mechanical models of structure. For the purpose of comparison. the seismic load was computed according to CED code requirements. The load was accepted in current investigations by assuming the magnitude of Richter scale $s_{m}=8$. Four discrete models of the structure are studied numerically. The 
first model assumes the structure of cryogenic equipment without covering modelled as an assemblage of classical beam elements FRM3 while the second model assumes the structure where the corner columns are modelled be a generalised element CFRM. The third and the fourth models assume the above two models with covering which is described by the wall element PANL. The involving or neglecting of the wall properties leads to quite different structural (mechanical) models, while differences in the modelling of corner columns have to be considered as various computational models.

Table 4. Comparison of maximal stresses due to different structure models:

a) the values of stresses for horizontal beam

\begin{tabular}{|c|c|c|c|c|}
\hline \multirow{2}{*}{$\begin{array}{c}\text { Mode } \\
\text { number } \\
i\end{array}$} & \multicolumn{4}{|c|}{ Maximal stresses $\sigma_{\max }(\mathrm{MPa})$} \\
\cline { 2 - 5 } & Model 1 & Model 2 & Model 3 & Model 4 \\
\hline 1 & 6.31 & 88.79 & 4.85 & 88.80 \\
\hline 2 & 22.75 & 90.19 & 24.15 & 90.19 \\
\hline 3 & 24.34 & 90.26 & 53.12 & 90.26 \\
\hline 4 & 55.46 & 90.27 & 74.28 & 90.27 \\
\hline 5 & 55.51 & 90.28 & 74.33 & 90.28 \\
\hline 6 & 57.97 & 90.34 & 76.66 & 90.34 \\
\hline 7 & 60.09 & 90.34 & 77.39 & 90.35 \\
\hline 8 & 61.02 & 90.35 & 79.15 & 90.35 \\
\hline
\end{tabular}

b) the values of stresses for corner column

\begin{tabular}{|c|c|c|c|c|}
\hline \multirow{2}{*}{$\begin{array}{c}\text { Mode } \\
\text { number } \\
i\end{array}$} & \multicolumn{5}{|c|}{ Maximal stresses $\sigma_{\max }(\mathrm{MPa})$} \\
\cline { 2 - 5 } & Model 1 & Model 2 & Model 3 & Model 4 \\
\hline 1 & 14.50 & 7.48 & 12.57 & 8.11 \\
\hline 2 & 50.87 & 7.60 & 60.41 & 8.19 \\
\hline 3 & 52.40 & 7.79 & 61.00 & 8.39 \\
\hline 4 & 82.09 & 7.85 & 95.99 & 8.42 \\
\hline 5 & 82.09 & 7.88 & 97.44 & 8.45 \\
\hline 6 & 82.42 & 7.88 & 97.91 & 8.45 \\
\hline 7 & 82.70 & 7.88 & 97.94 & 8.46 \\
\hline 8 & 83.11 & 7.89 & 98.84 & 8.46 \\
\hline
\end{tabular}


The values of the lowest frequencies of all four models are presented in table 3 , while the maximum stresses computed according to CED code requirements for beams and columns are presented in table 4 .

The frequency values illustrate the fact. that dynamic properties of the structure essentially depend on mechanical models. It means that the covering of the box stiffens the structure and shifts increasingly the frequency range. The two frequency spectra and response curves defining seismic loads are illustrated in fig. 8. Following to the design code requirements, in this frequency range NPD Code produces a single response curve, while CED code produces certain envelope of response values varying according to additional factors. The higher values of nuclear codes may be estimated quantitatively. In addition. CED specifies the limit of frequencies that has to be taken into account. From this picture it follows that for the model with covering only a single vibration mode producing seismic loading has to be taken into consideration.

The contribution of individual vibration modes in different discretisation models is illustrated graphically in fig. 9. The pictures are plotted for the intensity scale magnitude $s_{m}=8$, while for the other $s_{m}$ the stresses differ by a simple scalar factor. It is easy to find. that stresses occurring on the frame without covering are produced by several modes, while in the structure with covering they are mainly produced by a single mode. A covering dramatically reduces the stresses in columns (approximately 10 times) but increases the stresses of beams by order of $48 \%$. The application of a symmetric beam element model to non-symmetric sections leads to dangerous reduced values of stresses for the model with covering where a computation error reaches $22 \%$ for the beam and $16 \%$ for the column. For the model with covering the difference is negligibly small. Thus, only careful examination of different models may predict a desired order of safety margin of the designed structure.

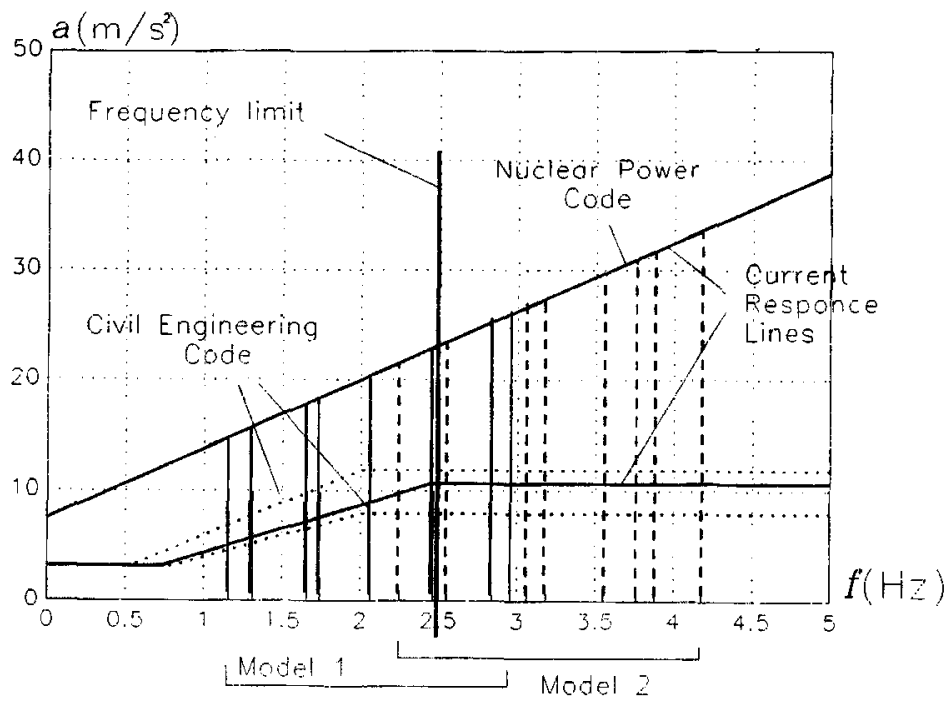

Fig. 8. Frequency spectra and response curves 

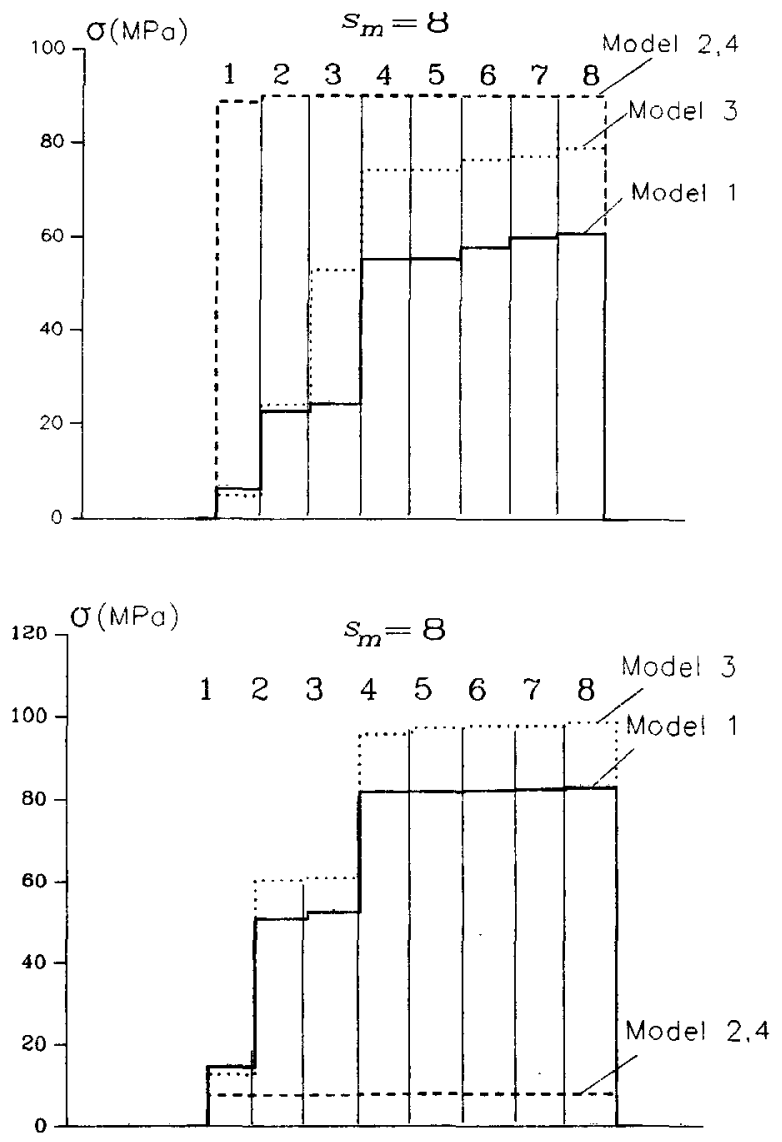

Fig. 9. Diagrams of the increasing contribution of individual vibration modes in different discretisation models:

a) for horizontal beam; b) for corner column

\section{Conclusions}

Modelling of the cryogenic structure under the seismic loading is considered in the paper. The structure under discussion represents a large metal box comprising a hermetic space for low temperature technologies. For design purpose a detailed time-dependent seismic analysis is replaced by more simple equivalent static force models, the methodology of which is defined by particular design codes. In this presentation, the above structure under the action of different seismic loads is tested numerically by the finite element method. Two kinds of factors - the seismic load and structure models are investigated.

Seismic loading is presented by two models. Theoretically, the equivalent static force methods should give an envelope of any real seismic stress history (time-dependent seismic load). It is obvious that Nuclear Power Design Code provides a higher stress level and larger safety margin than Civil Engineering Design Code does. This fact is, in general, observed in the results of modelling with the exception of a single peak value. 
The second group of examples is considered in order to compare different computational and mechanical models of structure. The involving or neglecting of the covering leads to quite different structural (mechanical) models, while differences in the modelling of corner columns have to be considered as various computational models. A covering dramatically reduces the stresses in columns but increases the stresses of beams. The application of a symmetric beam element model to non-symmetric sections leads to dangerous reduced values of stresses for the model with covering. Thus, comparison of different models may be used for predict of the behaviour of the designed structure.

\section{References}

1. R.W.Clough and J.Penzien. Structural dynamics, McGraw-Hill, New-York, 1975. 246 p.

2. The Seismic Design Handbook (ed. F.Naeim). New-York, Van Nostrand Reinhold, 1989. 538 p.

3. P.Leger, E.L.Wilson and R.W.Clough. The Use of Load Dependent Vectors for Dynamic and Earthquake Analysis, University of California, Berkeley California, 1986. 244 p.

4. A.K.Jain, Inelastic Response of Reinforced Concrete Frames Subjected to the 1985 Mexico Earthquake. Comp. Struct., 34, 3, 1990. P 445-454.

5. Строительные нормы и правила II-7-81, Часть II, Проектирование в сеисмических районах, Москва: Стройиздат, 1982. $216 \mathrm{c.}$

6. НГА-02-85. Часть 1. Москва, 1986. $186 \mathrm{c.}$

7. Р.Качянаускас, Р.Кутас, А.Саулис, С.Жюкас. Разработка комплекса программ для расчета кожухов ВРУ: Отчет по НИР. Вильнюс, 1990. 174 с.

8. Р.Качянаускас, Р.Кутас, А.Саулис, В.Василяускас, С.Жюкас. Разработка программ по расчету сейсмостойкости стержневых конструкций: Отчет по НИР. Вильнюс, 1991. 65 с.

9. R.Kačianauskas, R.Kutas. Kriogeninio jrenginio seismikos analizé baigtiniu elementy metodu // Lietuvos skaiciuojamosios mechanikos III seminaro darbai. Vilnius: Technika, 1994. P. 63-68.

\section{KRIOGENINIO ĮRENGINIO, VEIKIAMO SEISMINES APKROVOS, MODELIAVIMAS}

\section{R.Kačianauskas, R.Kutas}

\section{Santrauka}

Nagrinèjamas kriogeninio irenginio seisminès analizès uždavinys baigtiniu elementy metodu. Kriogenini ịrenginị sudaro erdvinis rèmas su lakštinio plieno apvalkalu.

Pateikiami du seisminio modeliavimo uždaviniai. Pirmajame uždavinyje pateikiamas toks seisminès analizès matematinis modelis, kuris ịvertina seisminị procesą laike. Tokio proceso pavyzdžiu paimtas žemès drebejjimas, ivykęs Mechike 1985 metais. Šame modelyje ittempimai gaunami integruojant pateiktą literatūroje Mechiko žemès drebèjimo pagreičių diagramą. Integravimas atliekamas dviem skirtingiems laiko žingsniams. Antruoju atveju seisminè apkrova modeliuojama, remiantis buvusios SSSR statybos ir atominès energetikos projektavimo normomis ir taisyklemis. Analizuojama taip pat skirtingu rèmo elementų ir apvalkalo modelių itaka seisminiam atsparumui.

Pateikiami išsamūs skaixiavimo rezultatai. Skaixiavimai atlikti baigtinį̨ elementy programy paketais, sukurtais VTU konstrukcijy skaitinio modeliavimo ir tyrimo laboratorijoje.

Palyginamieji modelių parametrai yra pavojingiausių kolonos ir rygelio maksimalūs įtempimai. Gauti rezultatai parodo, kad pagal atominès energetikos projektavimo normas apskaičiuoti ł̇tempimai praktiškai apgaubia seisminio proceso sukeltus įtempimus, o pagal civilinès statybos normas gauti įtempimai pasiekia tik vidutines jų reikšmes. 